\title{
WYPOWIEDZI OJCÓW KOŚCIOŁA NA TEMAT WIARY W INTERPRETACJI PAPIEŻA FRANCISZKA W ENCYKLICE LUMEN FIDEI
}

Pierwsza encyklika papieża Franciszka, rozpoczynająca się od słów $L u$ men fidei ${ }^{l}$, została zainspirowana przez Benedykta XVI, który pragnął takim dokumentem ukoronować Rok Wiary w Kościele powszechnym. Papież Franciszek pisze o tym we wstępie do wspomnianej encykliki:

„[Benedykt XVI] prawie skończył [...] prace nad pierwszym szkicem encykliki o wierze. Jestem mu za to głęboko wdzięczny i w duchu Chrystusowego braterstwa przejmuję jego cenne dzieło, dodając do tekstu kilka przemyśleń"².

Czytając cały tekst bardzo trudno jest wskazać (a właściwie jest to niemożliwe), które fragmenty pochodzą od papieża Franciszka, które zaś od Benedykta XVI. Arcybiskup Rino Fisichella, Przewodniczący Papieskiej Rady ds. Nowej Ewangelizacji, w komentarzu do encykliki Lumen fidei stwierdza: „encyklika ta podejmuje wprawdzie pewne przemyślenia i treści właściwe magisterium Benedykta XVI, jednak jest w pełni tekstem papieża Franciszka"3.

Nie wchodząc w jakąkolwiek polemikę, czy próby ustalenia, czyjego tekstu jest więcej, należy jedynie podkreślić, że obserwując pontyfikat papieża Benedyka XVI można było się przekonać, że w swoim nauczaniu bardzo często nawiązywał do myśli Ojców Kościoła, cytował ich wypowiedzi, analizował doktrynę zawartą w ich dziełach, odwoływał się do ich cennych spostrzeżeń. We wspomnianej encyklice zostały również przytoczone wypowiedzi Ojców Kościoła i pisarzy wczesnochrześcijańskich, co oznacza, iż papież Franciszek także lubi odwoływać się do tych wielkich świadków wiary. Wspomniane wypowiedzi Ojców są bardzo ważne z dwóch powodów. Po pierwsze spotykamy

* Ks. dr hab. Bogdan Czyżewski, prof. UAM - profesor nadzwyczajny w Zakładzie Teologii Patrystycznej na Wydziale Teologicznym Uniwersytetu im. Adama Mickiewicza w Poznaniu; e-mail: czybo@amu.edu.pl.

${ }^{1}$ Por. Franciscus papa, Litterae Encyclicae „Lumen fidei” (29 VI 2013), AAS 105 (2013) 555596, thum. polskie: Ojciec Święty Franciszek, Encyklika „Lumen fidei”. O wierze, Kraków 2013 (dalej używam skrótu: Lumen fidei z podaniem numeru dokumentu oraz strony polskiego wydania).

${ }^{2}$ Lumen fidei 7, s. 10.

${ }^{3}$ R. Fisichella, Wprowadzenie i komentarz do encykliki Lumen fidei, w: Ojciec Święty Franciszek, Lumen fidei. Światto wiary, Częstochowa 2013, 9. 
wybrane teksty pisarzy okresu patrystycznego na temat wiary w tak doniosłym dokumencie papieskim, jakim jest encyklika; po drugie zaś, mamy okazję poznać je w interpretacji dwóch papieży: Benedykta XVI i Franciszka.

Jeżeli chcielibyśmy podać dokładną liczbę odwołań do tekstów wczesnochrześcijańskich w encyklice Lumen fidei, należałoby powiedzieć, że jest ich wiele, biorąc pod uwagę fakt, że wydany w języku polskim tekst liczy tylko 72 strony. Najczęściej cytowany jest św. Augustyn (11 razy), następnie św. Ireneusz z Lyonu (3 razy), św. Justyn i Orygenes (po 2 razy), jednokrotnie natomiast List Barnaby, Klemens Aleksandryjski, Tertulian, św. Cyryl Jerozolimski, św. Leon Wielki i św. Grzegorz Wielki.

Zadaniem niniejszego studium będzie zatem analiza wypowiedzi wymienionych Ojców Kościoła i pisarzy kościelnych przywołanych we wspomnianej encyklice papieża Franciszka, oraz próba odnalezienia podstawowych tematów teologicznych pojawiających się w kontekście zagadnienia wiary.

1. Droga ludzi wiary. Pierwszy temat jaki podsuwają Ojcowie Kościoła papieżowi to przykłady ludzi wiary i ich droga do wiary. Zanim jednak zostana przywołane konkretne postaci, Franciszek nawiązuje do greckiej i łacińskiej etymologia słowa ,wiara”. W związku z tym powołuje się na św. Cyryla Jerozolimskiego:

„Nawiązując do obu znaczeń tego słowa - obecnych również w odpowiadających im wyrazach: greckim (pistòs) i łacińskim (fidelis) - św. Cyryl Jerozolimski podkreśla godność chrześcijanina, który otrzymuje to samo imię co Bóg: jeden i drugi nazywani są wiernymi"'4.

Zdaniem papieża wyjaśnienie powyższego stwierdzenia biskupa Jerozolimy odnaleźć można u św. Augustyn, który w Objaśnieniach Psalmów powiada: „Człowiek wierzy obietnicom Boga. Bóg wierny spełnia to, co przyrzekł człowiekowi"s. Oznacza to, że wiara zakorzeniona jest w Bogu, w Nim też posiada swoje źródło. Bóg bowiem jest konsekwentny w swoim działaniu i słowach, nie mija się z prawda, co więcej, wypełnia i daje to, co obiecał. Dlatego też człowiek w naturalny sobie sposób winien odpowiadać wiarą i zaufaniem na taką postawę Boga i nie musi się obawiać, że zostanie oszukany.

Papież uzasadnia także sam tytuł encykliki - Lumen fidei w oparciu o wypowiedzi Ojców Kościoła. Jest to także poniekąd wskazanie na ważność podejmowanego tematu. Nawiązując do pogańskiego kultu boga Słońca - Sol invictis - papież Franciszek stwierdza, że samo słońce nie jest w stanie ogarnąć wszystkich tajemnic życia człowieka. Dla poparcia tego cytuje jednocześnie

${ }^{4}$ Lumen fidei 10, s. 14-15; por. Cyrillus Hierosolymitanus, Ad illuminandos catechesis V 1, PG 33, 505A, tłum. W. Kania: Cyryl Jerozolimski, Katechezy przedchrzcielne i mistagogiczne, BOK 14, Kraków 2000, 79.

${ }_{5}^{5}$ Lumen fidei 10, s. 15; Augustinus, Enarrationes in Ps. 32(2), 9, PL 36, 284, thum. J. Sulowski: Św. Augustyn, Objaśnienia Psalmów, PSP 37, Warszawa 1986, 303. 
św. Justyna, który w Dialogu z Żydem Tryfonem stwierdza, że „Nie spotkano nikogo gotowego umrzeć za swą wiarę w słońce" ". Inaczej jest natomiast w przypadku chrześcijan, którzy potrafią oddać życie za Chrystusa. On dopiero jest prawdziwym słońcem, w taki bowiem sposób nazywali Go chrześcijanie, a Jego „promienie dają życie" . Żadna zatem śmierć za Chrystusa nie jest bezsensowna; mimo że człowiek oddaje życie, to tak naprawdę dopiero je zyska. Ojciec Święty rozwija podjęty wątek nawiązując do Akt męczenników. Cytuje mianowicie fragment dialogu rzymskiego prefekta Rustyka z chrześcijaninem Hieraksem:

„Gdzie są twoi rodzice? - pytał sędzia męczennika, a ten odpowiedział: Naszym prawdziwym ojcem jest Chrystus, a naszą matką wiara w Niego"s.

Światło wiary nadaje zatem sens ludzkiej egzystencji, zwłaszcza w obliczu śmierci oraz pozwala człowiekowi spotkać się z żywym Bogiem, nie tylko w wieczności, lecz także w całym ziemskim życiu?.

Postacią, która nie tylko dla papieża Franciszka, ale także dla św. Augustyna pozostaje przykładem człowieka wiary, jest oczywiście Abraham. Ojciec Swięty uzasadnia to w następujący sposób:

„wiara Abrahama kierowała się ku Niemu, była w pewnym sensie antycypowaną wizją Jego tajemnicy. Tak pojmuje to św. Augustyn, gdy twierdzi, że Patriarchowie zbawili się w wierze, nie w wierze w Chrystusa, który już przyszedł, ale w wierze w nadchodzącego Chrystusa, w wierze skierowanej ku przyszłemu wydarzeniu Jezusa"10.

Nawiązując zaś do tematu zbawienia przez wiarę i uczynki, który tak często podejmował św. Paweł w polemice $\mathrm{z}$ faryzeuszami, papież, podobnie jak Apostoł Narodów, odcina się od usprawiedliwienia samego siebie przed Bogiem poprzez własne uczynki. Mówi bowiem, że przyjęcie takiej postawy powoduje odrzucenie Boga jako źródła sprawiedliwości. Człowiek stawia siebie w centrum, izoluje od innych, zwłaszcza zaś od Boga i wszystko, co próbuje czynić staje się bezowocne, ponieważ podobny jest do drzewa, które nie

\footnotetext{
${ }^{6}$ Lumen fidei 1, s. 5; Justinus, Dialogus cum Tryphone Judaeo 121, 2, PG 6, 758, thum. L. Misiarczyk: Justyn Męczennik, Dialog z Żydem Tryfonem, Warszawa 2012, 296.

${ }^{7}$ Lumen fidei 1, s. 5; Clemens Alexandrinus, Protrepticus IX 84, 2 PG 8, 196B, thum. J. Sołowianiuk, w: Apologie (Minucjusz Feliks, Oktawiusz; Do Diogneta; Klemens Aleksandryjski, Zachęta Greków), PSP 44, Warszawa 1988, 179.

${ }^{8}$ Lumen fidei 5, s. 9; Martyrium S. Justini et sociorum, ed. D.R. Knopf, w: Ausgewählte Märtyrerakten, Tübingen 1913, 17, tłum. A. Lisiecki, w: Św. Justyn, Apologia, Dialog z Żydem Tryfonem, POK 4, Poznań 1926, s. XXIV.

${ }^{9}$ Por. Lumen fidei 4, s. 7-8.

${ }^{10}$ Tamże 15, s. 19-20; por. Augustinus, In Joannis Evangelium tractatus 45, 9, PL 35, 1722 1723, tłum. W. Szołdrski - W. Kania, w: Św. Augustyn, Homilie na Ewangelie i pierwszy List św. Jana, PSP 15/1, Warszawa 1977, 537-538.
} 
czerpie wody, gdyż ta znajduje się zbyt daleko ${ }^{11}$. Papież Franciszek obrazuje taką sytuację słowami św. Augustyna, które przytacza także w wersji łacińskiej: ,Ab eo qui fecit te noli deficere nec ad te - od Tego, który cię uczynił, nie oddalaj się, nawet zmierzając do siebie"12. Papież przytoczone słowa biskupa Hippony nazywa precyzyjnym i sugestywnym językiem ${ }^{13}$.

2. Wiara a rozum. Stosunkowo liczne wypowiedzi Ojców Kościoła w encyklice Franciszka pojawiają się w związku z tematem relacji, jaka zachodzi pomiędzy wiarą a rozumem. Jest to całkowicie zrozumiałe kiedy weźmie się pod uwagę fakt, że pisarze wczesnochrześcijańscy wiele miejsca poświęcali fides et ratio. Papież Franciszek powołuje się na syntezę słów „zrozumieć” i „ostać się”, które św. Augustyn zawarł w swoich Wyznaniach, kiedy „mówi o prawdzie, której można zawierzyć, aby móc stać mocno"14. Biskup Hippony stwierdza: „Wtedy okrzepnę i umocnię się w Tobie, [...] w Twojej prawdzie"15. Papież Franciszek wyjaśnia przytoczone zdanie w ten sposób:

„,́́w. Augustyn pragnie ukazać, w jaki sposób ta wiarygodna prawda Boża jak świadczy o tym Biblia - jest Jego wierną obecnością w dziejach, Jego zdolnością scalenia razem czasu i gromadzenia rozproszonych dni człowieka"16.

Papież mówiąc o prawdzie poszukiwanej przez człowieka i nadającej sens jego drodze zauważa w tym procesie rolę miłości. Gdzie jest ona obecna, tam jest prawda, ponieważ:

„Kto kocha, rozumie, że miłość jest doświadczeniem prawdy, że to ona otwiera nasze oczy, byśmy mogli zobaczyć całą rzeczywistość w nowy sposób, w jedności z kochaną osobą" ${ }^{17}$.

Potwierdzeniem tego są dla papieża Franciszka słowa św. Grzegorza Wielkiego, który w swoich Homiliach na Ewangelie napisał, że ,, amor ipse notitia est - sama miłość jest poznaniem, niesie z sobą nową logikę"18. Inaczej mówiąc, postrzeganie świata i poznawanie go, jak również poznawanie prawdy dokonuje się nie pojedynczo, ale we wspólnocie, $\mathrm{z}$ kochaną osobą $\mathrm{i}$ jest wówczas patrzeniem wspólnym, w tym samym kierunku ${ }^{19}$.

\footnotetext{
${ }^{11}$ Por. Lumen fidei 19, s. 24-25.

${ }^{12}$ Tamże 19, s. 25; Augustinus, De continentia 4, 11, PL 40, 356, thum. S. Laskowski, w: Pisma świętego Augustyna o malzeństwie i dziewictwie, red. A. Eckmann, Lublin 2003, 314.

${ }^{13}$ Por. Lumen fidei 19, s. 25.

${ }^{14}$ Tamże 23, s. 30.

${ }^{15}$ Tamże; Augustinus, Confessiones XI 30, 40, PL 32, 825, tłum. Z. Kubiak: Święty Augustyn, Wyznania, Warszawa 1992, 375.

${ }^{16}$ Lumen fidei 23, s. 30.

${ }^{17}$ Tamże 27, s. 34.

${ }^{18}$ Tamże; Gregorius Magnus, In Evangelia hom. II 27, 4, PL 76, 1207, thum. anonimowe: Św. Grzegorz Wielki, Homilie na Ewangelie, Warszawa 1998, 42.

${ }^{19}$ Por. Lumen fidei 27, s. 34.
} 
Te rozważania dotyczące prawdy, miłości, poznania prowadzą papieża do stwierdzenia za św. Augustynem, iż uwierzyć oznacza dotknąć kogoś sercem (Tangere autem corde, hoc est credere) ${ }^{20}$. Okazuje się, że biskup Hippony dochodzi do takiego przekonania, kiedy komentuje fragment Ewangelii o kobiecie cierpiącej na krwotok i dotykającej Jezusa, aby ją uzdrowił (por. Łk 8, 45-46). Papież jakby kontynuując myśl św. Augustyna stwierdza, że chociaż tłum ludzi ciśnie się wokół Jezusa, to jednak:

„nie dotyka Go osobowym dotknięciem wiary, uznającym Jego tajemnicę, to, że jest Synem objawiającym Ojca. Dopiero kiedy zostajemy upodobnieni do Jezusa, otrzymujemy właściwe oczy, aby Go zobaczyć'”21.

Można zatem powiedzieć, że początkiem wiary jest łaska przemieniająca serce człowieka. Pierwszy ruch należy więc do Boga, On bowiem powołuje, a także pozwala siebie zobaczyć i dotknąć. Dotknięte ludzkie serce przez Ducha Świętego umożliwia rozpoznanie Jezusa jako Zbawiciela ${ }^{22}$.

Wiele miejsca poświęca papież Franciszek wyjaśnieniu relacji wiary i rozumu w życiu św. Augustyna. Dlatego wraca do jego Wyznań, do nawrócenia, do tego wszystkiego, co mu towarzyszyło, zanim uwierzył. Papież dostrzega u przyszłego biskupa Hippony przykład dwóch dróg, które nie wykluczają się, lecz wzajemnie uzupełniają. Pierwszą nazwać można rozumem, a zatem tym wszystkim, co poszukujemy w życiu, by stać się ludźmi wiedzącymi. W przypadku św. Augustyna była to miłość do greckiej filozofii światła, konkretnie zaś do neoplatonizmu, który głosił ,paradygmat światła zstępującego z wysoka, by oświecić rzeczy"23. Franciszek uważa, że dzięki temu św. Augustyn nie tylko uwolnił się od zgubnego manicheizmu, który deklarował ustawiczną walkę dobra i zła, ale także zrozumiał Boską transcendencję oraz odkrył, że to Bóg jest światłem i dzięki Niemu poznał całe zło swojego życia i skierował swoje serce ku dobru. Można zatem, zdaniem Ojca Świętego, mówić o wzajemnym przenikaniu się rozumu i wiary, to bowiem, co zostało zyskane jako wiedza, pomogło Augustynowi uwierzyćc ${ }^{24}$.

Istnieje w życiu biskupa Hippony jeszcze druga droga, mianowicie decydujący moment, kiedy uwierzył. Pomógł mu w tym tajemniczy głos Boga: „Weź to, czytaj!”25, na który Augustyn bez wahania odpowiedział, ponieważ wziął do ręki tom listów św. Pawła i zatrzymał się przy rozdziale 13. Listu do Rzymian. Papież zwraca uwagę, że św. Augustyn uwierzył nie dlatego, iż zobaczył Boga, ale dlatego, że usłyszał w ogrodzie głos. Wiary zatem nie można ograniczyć wyłącznie do poznania empirycznego, Bóg często przemawia do

\footnotetext{
${ }^{20}$ Tamże 31, s. 39; Augustinus, Sermo 14 (Tractatus de quinta feria Sanctae Paschae), PLS 2, 576.

${ }^{21}$ Lumen fidei 31, s. 39-40.

${ }^{22}$ Por. Fisichella, Wprowadzenie, s. 14.

${ }^{23}$ Lumen fidei 33, s. 41-42.

${ }^{24}$ Por. tamże.

${ }^{25}$ Tamże 33, s. 42; Augustinus, Confessiones VIII 12, 29, PL 32, 762, thum. Kubiak, s. 241.
} 
człowieka, ten zaś winien słuchać i odpowiadać postawą wiary na to, co On do niego mówi ${ }^{26}$.

W tym miejscu papież dochodzi do syntezy wiedzy i wiary w życiu św. Augustyna. Słusznie bowiem stwierdza, że chociaż dopełnieniem wiary u przyszłego biskupa Hippony było spotkanie z „Bogiem Słowa”, czyli odnalazł ją w Piśmie Świętym, to jednak nie odrzucił wiedzy, czyli tego, co pomogło mu też uwierzyć. Połączył on słuchanie z widzeniem, czyli wiarę z wiedza, o czym sam napisał w dziele De Trinitate, mianowicie o ,słowie jaśniejącym we wnę-

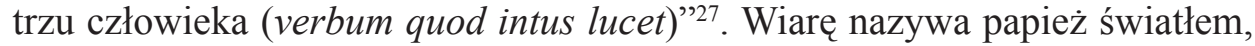
które oświeca słowo, czyli wiedzę. Ono też wzywa człowieka i pragnie „wizji całości, a nie tylko fragmentów historii" ${ }^{28}$. Zdaniem św. Augustyna spełni się całkowicie to pragnienie, kiedy człowiek będzie oglądał i kochał ${ }^{29}$, czyli gdy cały wejdzie w światło, co oznacza, że całkowicie zanurzy się w Bogu ${ }^{30}$.

Wątek związany z relacją wiary do rozumu podejmuje papież także w odniesieniu do Abrahama. Powołuje się na św. Ireneusza z Lyonu, który zwraca uwagę, iż wspomniany patriarcha zanim usłyszał głos Boga, wcześniej Go poszukiwał „W żarliwym pragnieniu swego serca”. W tym celu ,przemierzał cały świat, pytając się, gdzie jest Bóg”, aż w końcu „Bóg zlitował się nad tym, który szukał Go sam w milczeniu" ${ }^{31}$. Papież Franciszek wyciaga z tego wniosek dla życia chrześcijańskiego i stwierdza, że każdy,

„Kto rusza w drogę, by czynić dobro, już zbliża się do Boga, już jest wspierany Jego pomocą ponieważ to właśnie siła Bożego światła oświeca nasze oczy, gdy zmierzamy ku pełni miłości”32.

3. Dzielenie się wiarą. Papież Franciszek podejmuje także w swojej encyklice ważne zagadnienie związane z dzieleniem się wiarą przez człowieka, co wynika, jego zdaniem, z samej jej natury. Wiara bowiem

„dąży do tego, by się rozpowszechniać, zapraszać innych do swej radości.

Człowiek otrzymujący wiarę odkrywa, że poszerzają się przestrzenie jego ja i nawiązują się nowe relacje, które ubogacają życie"33.

${ }^{26}$ Por. Lumen fidei 33, s. 42.

${ }^{27}$ Tamże; Augustinus, De Trinitate XV 11, 20, PL 42, 1071, thum. M. Stokowska: Św. Augustyn, O Trójcy Świętej, Kraków 1996, 482.

${ }^{28}$ Lumen fidei 33, s. 42.

${ }^{29}$ Por. tamże; Augustinus, De civitate Dei XXII 30, 5, PL 41, 804, thum. W. Kornatowski: Święty Augustyn, O państwie Bożym przeciw poganom ksiag XXII, t. 2, Warszawa 1977, 617, Lumen fidei 33, 42.

${ }^{30}$ Por. Lumen fidei 33, s. 42.

${ }^{31}$ Tamże 35, s. 46; Irenaeus Lugdunensis, Demonstratio praedicationis apostolicae 24, ed. A. Rousseau, SCh 406, Paris 1995, 117, tłum. W. Myszor: Ireneusz z Lyonu, Wyktad nauki apostolskiej, ŹMT 7, Kraków 1997, 43.

${ }^{32}$ Lumen fidei 35, s. 46.

${ }^{33}$ Tamże 39, s. 52. 
Wyraźnym tego przykładem jest dla papieża Tertulian, który w dziele De baptismo, mówiąc o katechumenie stwierdza, że

„po obmyciu nowego narodzenia zostaje przyjęty w domu Matki, aby wyciągnąc ręce i wraz z braćmi modlić się Ojcze nasz, niejako przyjęty w nowej rodzinie" ${ }^{\prime 34}$.

Ojciec Święty zauważa też ścisły związek, jaki zachodzi pomiędzy chrztem i wiarą. Przypomina on, że pisarze wczesnochrześcijańscy, jak chociażby Barnaba $^{35}$, powołując się na tekst proroka Izajasza 33, 16: „twierdze na skałach będą jego schronieniem; [...] wody mu nie zabraknie", odczytują go w kontekście chrztu św. Papież Franciszek interpretuje to w następujący sposób:

„Ochrzczony, uratowany z wód śmierci, mógł stanąć na twardej skale, ponieważ znalazł moc, na której mógł się oprzeć. I tak woda śmierci przemieniła się w wodę życia. Tekst grecki opisywał ją jako wodę pistós, wodę wiernq. Woda chrztu jest wierna, ponieważ można jej się zawierzyć, ponieważ jej strumień włącza w dynamikę miłości Jezusa, źródło pewności dla naszej drogi życia" ${ }^{\prime 36}$.

Przekazywanie wiary, zdaniem papieża, dokonuje się przy współudziale Kościoła i rodziny, co podkreśla św. Augustyn. Biskup Hippony zwraca bowiem uwagę na podwójne powołanie rodziców. Pierwsze polega na daniu dzieciom życia, drugie natomiast związane jest z prowadzeniem ,ich do Boga, aby przez chrzest odrodziły się jako dzieci Boże i otrzymały dar wiary" ${ }^{37}$. Franciszek zaznacza, że dzięki powiązaniu dwóch wspomnianych rzeczywistości: życia i wiary dane zostaje dzieciom

„zasadnicze ukierunkowanie oraz pewność dobrej przyszłości; ukierunkowanie, które następnie zostanie potwierdzone w sakramencie bierzmowania przez szczególne znamię Ducha Świętego"38.

Nieco miejsca poświęca też papież Franciszek jedności i spójności wiary. Przekonuje on za św. Leonem Wielkim, że ,jeśli wiara nie jest jedna, nie jest wiarą"39. Jesteśmy bowiem kimś jednym w Ciele Chrystusa, wiara zaś jest

${ }^{34}$ Tamże; Tertullianus, De baptismo 20, 5, ed. J.W.Ph. Borleffs, CCL 1, Turnhout 1954, 295 , tłum. E. Stanula: Tertulian, Wybór pism, PSP 5, Warszawa 1970, 154.

${ }^{35}$ Por. Lumen fidei 42, s. 55-56; Epistula Barnabae 11, 5, ed. R.A. Kraft - P. Prigent, SCh 172, Paris 1971, 162, tłum. A. Świderkówna, w: Pierwsi świadkowie, BOK 10, Kraków 2010, 190.

${ }^{36}$ Lumen fidei 42, s. 55-56.

${ }^{37}$ Augustinus, De nuptiis et concupiscentia I 4, 5, PL 44, 413: „Habent quippe intentionem generandi regenerandos, ut qui ex eis saeculi filii nascuntur in Dei filios renascantur”, thum. własne; por. Lumen fidei 43, s. 56.

${ }^{38}$ Lumen fidei 43, s. 57.

${ }^{39}$ Tamże 47, s. 60; Leo I papa, Sermo 24 (In nativitate Domini IV) 6, ed. J. Leclercq - R, Dolle, SCh 22bis, Paris 1949, 110, thum. K. Tomczak: Św. Leon Wielki, Mowy, POK 24, Poznań - Warszawa - Lublin 1958, 94. 
jedna, ponieważ Chrystus jest jednością, a wszystkie prawdy wiary do Niego się odnoszą i pomagają poznać Jego istotę i działania ${ }^{40}$. Potwierdzenie tego odnaleźć można, zdaniem papieża, u św. Ireneusza z Lyonu, który podjął polemikę z gnostykami, m.in. w związku z ich poglądami na temat wiary, którzy twierdzili, że:

„istnieją dwa rodzaje wiary: wiara prymitywna, wiara ludzi prostych, niedoskonała, pozostająca na poziomie ciała Chrystusa i kontemplacji Jego tajemnic; i wiara innego rodzaju, głębsza i doskonała, wiara prawdziwa, zastrzeżona dla wąskiego kręgu wtajemniczonych, która dzięki intelektowi wznosiła się ponad ciało Jezusa, ku tajemnicom nieznanego Bóstwa" ${ }^{\text {"41 }}$.

Papież Franciszek, kierując się myślą biskupa Lyonu przekonuje, że wiara jest jedna, gdyż dotyka faktu wcielenia Chrystusa, a zatem Jego ciała i historii życia. W tych bowiem rzeczywistościach Bóg pragnął objawić się światu. Dlatego też, nie można dzielić wiary i mówić o istniejącej różnicy w wierze między tym:

„który potrafi mówić o niej dłużej i tym, który mówi o niej niewiele, między tym, który jest wyższy i tym mniej zdolnym: ani pierwszy nie może jej poszerzyć, ani drugi pomniejszyć"².

Temat jedności wiary często pojawiał się w literaturze patrystycznej, co zauważa też papież Franciszek:

„Ojcowie Kościoła opisywali wiarę jako jedno ciało, ciało prawdy z różnymi członkami, analogicznie do ciała Chrystusa i jego przedłużenia w Kościele"43.

Papież podkreśla również:

„Integralność wiary - wiązana była także z obrazem Kościoła dziewicy, z jego wiernością w oblubieńczej miłości do Chrystusa; niszczenie wiary oznacza niszczenie komunii z Panem"44.

Wynika z tego, że wiarę należy pojmować i przeżywać eklezjalnie. Chociaż jest ona osobistym wyborem każdego człowieka, to jednak równoznaczna jest z przynależnością do Kościoła. Papież powiada, że ten, kto wierzy, nie jest sam, ponieważ nie można wierzyć samotnie ${ }^{45}$. Dlatego dzielenie się wiarą następuje właśnie we wspólnocie Kościoła, w nim też znajduje ona swoją

${ }^{40}$ Por. Lumen fidei 47, s. 60-61.

41 Tamże 47, s. 61.

42 Tamże; Irenaeus, Adversus haereses I 10, 2, ed. A. Rousseau - L. Doutreleau, SCh 264, Paris $1979,160$.

${ }^{43}$ Lumen fidei 48, s. 62; Irenaeus, Adversus haereses II 27, 1, SCh 294, 264.

${ }^{44}$ Lumen fidei 48, s. 62; por. Augustinus, De sancta virginitate 48, 48, PL 40, 424-425: „Servatur et in fide inviolata quaedam castitas virginalis, qua Ecclesia uni viro virgo casta coptatur", thum. P. Nehring, w: Św. Augustyn, Pisma monastyczne, ŹM 27, Tyniec - Kraków 2002, 339.

${ }^{45}$ Por. Lumen fidei 39, s. 51. 
jedność oraz spójność, ponieważ Kościół jest jednym ciałem Chrystusa i działa w nim jeden i ten sam Duch Święty.

4. Owoce wiary. Powołując się na teksty Ojców Kościoła dotyczące wiary i życia wiara, papież Franciszek dostrzega jeszcze jeden ważny temat. Pisarze wczesnochrześcijańscy mówią o owocach wiary. Jednym z nich jest z pewnością godność każdej osoby. Aby wyjaśnić ten wątek Ojciec Święty powołuje się na Orygenesa, konkretnie zaś na podjętą przez niego polemikę z Celsusem, któremu trudno było pojać prawdę ,że Bóg stworzył świat dla człowieka, stawiając go na szczycie całego kosmosu" ${ }^{\prime 4}$. Nie potrafił też Celsus uznać, że „trawy [...] rosną w większym stopniu dla ludzi niż dla dzikich zwierząt pozbawionych rozumu" ${ }^{47}$. Celsus dodawał jeszcze, że jeżeli ktokolwiek patrzyłby z nieba na ziemię, nie zauważyłby, ,że nasze czyny różnią się w czym-

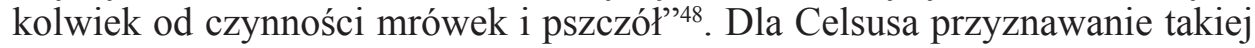
godności człowiekowi równało się z iluzją i oszustwem, co w starożytnym pogańskim świecie było raczej poglądem powszechnym. Papież ustosunkowując się niejako do zarzutów stawianych przez Celsusa chrześcijanom stwierdza, że to właśnie dzięki wierze człowiek pojmuje niepowtarzalną godność każdej osoby ludzkiej. Co więcej, w „,centrum wiary biblijnej jest miłość Boga, Jego konkretna troska o każdą osobę, Jego plan zbawienia, który obejmuje całą ludzkość i całe stworzenie, a który osiąga szczyt we Wcieleniu, Śmierci i Zmartwychwstaniu Jezusa Chrystusa" ${ }^{\text {"49 }}$.

$\mathrm{O}$ drugim owocu wiary papież Franciszek wspomina w związku ze św. Justynem, męczennikiem. Powołuje się mianowicie na użyte przez niego sformułowanie w odniesieniu do Maryi. Otóż przyjmując orędzie anioła Maryja poczęła „wiarę i radość” ${ }^{50}$. Komentując to wyrażenie, Ojciec Święty stwierdza:

„Wiara Matki Jezusa była bowiem owocna, a kiedy nasze życie duchowe przynosi owoce, napełnia nas radość, będąca najbardziej wyraźnym znakiem wielkości wiary" ${ }^{\prime \prime}$.

Wiara nie posiada zatem w sobie nic z przemocy i fanatyzmu, ze zła i smutku. Należy o niej powiedzieć, że zrodzona jest z miłości, dlatego wszelkie owoce jakie przynosi są nie tylko dobre, ale przesiąknięte miłością. Życie wiarą zakłada taki styl życia, który wyklucza zło, rodzi natomiast radość, która zawsze pozostaje owocem miłości, a zatem i wiary.

${ }^{46}$ Tamże 54, s. 69.

${ }^{47}$ Tamże 54, s. 69-70; Origenes, Contra Celsum IV 75, ed. M. Borret, SCh 136, Paris 1968, 372 , thum. S. Kalinkowski: Orygenes, Przeciw Celsusowi, Warszawa 1986, 231.

${ }^{48}$ Lumen fidei 54, s. 70; Origenes, Contra Celsum IV 85, SCh 136, 394, thum. Kalinkowski, s. 237.

${ }^{49}$ Lumen fidei 54 , s. 70.

${ }^{50}$ Tamże 58, s. 75; por. Justinus, Dialogus cum Tryphone Judaeo 100, 5, PG 6, 710, thum. Misiarczyk, s. 273.

${ }^{51}$ Lumen fidei 58, 75. 
Podsumowując wypowiedzi Ojców Kościoła, które pojawiły się w encyklice papieża Franciszka Lumen fidei należy stwierdzić, że w dużym stopniu wyznaczają one najważniejsze tematy związane $\mathrm{z}$ doświadczeniem wiary w życiu człowieka. Jeżeli uznamy prawdę, że sercem wiary jest trynitarna miłość Boga objawiona w Jezusie Chrystusie, wówczas trzeba przyznać, iż miłość rodzi wiarę, ta zaś podtrzymuje miłość. Stąd też biorą się określenia „światło wiary” i ,światło miłości”. Te dwie rzeczywistości stanowią drogę prowadząca do poznania Boga. Okazuje się, że Ojcowie Kościoła wypowiadając się na temat wiary w życiu człowieka ukazują drogę miłości prowadzącą do wiary. Nie brakuje też refleksji związanych z relacją wiary do rozumu, gdzie ponownie dochodzi do głosu miłość. Wiara bowiem zrodzona z miłości w naturalny dla siebie sposób szuka prawdy i pragnie ją poznać. Dlatego należy mówić o głębokim związku tych dwóch rzeczywistości - fides et ratio. Wiara $\mathrm{w}$ końcu domaga się dzielenia $\mathrm{z}$ innymi, powinna być przekazywana we wspólnocie Kościoła. Umacnia się zaś przez to, że wydaje owoce i powoduje zmianę życia u tego, kto wierzy. Należy dodać, że cała encyklika papieża Franciszka jest głębokim i ważnym przesłaniem dla Kościoła i doskonałą analizą teologiczną problematyki wiary, którą z pewnością pomagają lepiej zrozumieć pisarze wczesnochrześcijańscy. Dla nich przecież wiara także stanowiła punkt wyjścia i odniesienia na drodze prowadzącej ich do Boga.

\section{CHURCH FATHERS' QUOTES ON FAITH IN THE INTERPRETATION OF POPE FRANCIS IN THE ENCYCLICAL LETTER LUMEN FIDEI}

\section{(Summary)}

The first Encyclical Letter of Pope Francis, commencing with the word "Lumen fidei", contains valuable statements of the Church Fathers on the topic of faith. The Holy Father examines and interprets them in the context of his own reflections. He quotes St. Augustine (11 times), St. Irenaeus of Lyons (3 times), St. Justin and Origen (each 2 times) and the Epistle of Barnabas, Clement of Alexandria, Tertullian, St. Cyril of Jerusalem, St. Leo the Great and St. Gregory the Great. The texts of the Church Fathers, cited by the Pope, are focused on four main themes. The first is related to the way, that leads a man to faith, which is born through love looking for truth. Therefore, there is a deep relationship between two realities - fides et ratio. Faith finally demands to be shared with others, and is transmitted in the community of the Church. She is strengthened by the fact, that it bears fruit, and will change the lives of those, who believe.

Key words: faith, pope Francis, love, knowledge, Church Fathers.

Słowa kluczowe: wiara, papież Franciszek, miłość, poznanie, Ojcowie Kościoła. 